\title{
Domestic and Foreign Origin Foodstuff Prices Comparison in Selected Retail Chains
}

\author{
Ondřej Škubna ${ }^{1}$, Jaroslav Homolka ${ }^{1}$, Anna Vladimirovna Belova ${ }^{2}$ \\ 1 Faculty of Economics and Management, Czech University of Life Sciences in Prague, Czech Republic \\ 2 Independent expert, St. Petersburg, Russia
}

\begin{abstract}
The main objective is to verify whether it is possible to confirm differences in price policy not only in the division of chains according to the format of the shops but also in relation to Czech and foreign food and whether these findings can be clearly identified. The partial objective is to find the difference between Czech and foreign products in the context of chain approach according to other criteria such as price differences among products and among chains. There are eleven chains evaluated in the tables as well as 29 relevant food groups. The used underlying data is based on the data processed from the primary data obtained by the data collection in the retail chains. The average number of observations of one item, which is about 43 observations, of which 37 observations of Czech products and about 29 products with price. Only Lidl has a higher number of price observations from the total number of observations of foreign products. In the area of price policy evaluation (whether it is possible to confirm the differences not only in the division of the chains according to the format of the stores, but also in relation to Czech and foreign foods and identify clearly these findings), the difference is considered mainly according to the "low price" of food and it can be said that there are noticeable differences among the chains, which also confirm different approach to Czech and foreign food and differences according to the format of chain stores. This paper originated in the context of the exploratory study „Prices of selected Czech and foreign food products in retail chains in November 2016“. The study was created for the needs of the Ministry of Agriculture of the Czech Republic.
\end{abstract}

\section{Keywords}

Foodstuffs, Czech products, foreign products, retail chain, price, format of stores, foodstuff offer, foodstuff price, price policy.

Škubna, O., Homolka, J and Belova, A. V. (2017) "Domestic and Foreign Origin Foodstuff Prices Comparison in Selected Retail Chains", AGRIS on-line Papers in Economics and Informatics, Vol. 9, No. 4, pp. 99-108. ISSN 1804-1930. DOI 10.7160/aol.2017.090410.

\section{Introduction}

The global food market is nowadays highly concentrated at both regional and national level (Svatoš et al., 2012; Bielik et al., 2013). The food market is dominated by only a limited group of key actors (retail chain owners) who control the decisive share of food supply in the market. A particularly high level of concentration can be observed in the countries of the European Union (Smutka et al., 2016; Maitah et al., 2016). This ongoing process of concentrating the food market can be successfully demonstrated on the example of the Czech Republic. The number of actors active on the Czech market has considerably decreased over the past twenty years (Smutka et al., 2013). Independent stores and supermarkets have disappeared, and due to the worsening market conditions, even some of the larger chains have left the Czech market (Delvita, Julius Meinl, Interspar, Carrefour, etc.).

Major part of the food retail market ceased to be owned by domestic capital, due to the significant concentration of the market. Only the COOP retail chain can be considered as of domestic origin, other actors are owned by foreign capital. These are retail chains from Germany, the Netherlands and the United Kingdom. Since most market players do not originate from the Czech Republic and given that most sales capacities operate as a subsidiary of a global parent company, it can be assumed that 
the domestic sales strategies of these chains are not primarily formulated on the domestic market but are prepared in context of broader strategies of parent companies.

Rather speculative question arises, which is occupying both Czech political and professional scene in regards of what have been said. It is a question of a different approach of these companies in relation to the origin of the goods. Whether transnational chains tend to prefer foreign goods to domestic products as part of their wider business strategies. Some representatives in this regard even speculate whether the goal of transnational retail chains is to reduce agricultural production capacities in the Czech Republic and therefore to reduce self-sufficiency in animal production (Špička et al., 2014; К̌ezbová et al., 2012) and plant production (Pulkrábek et al., 2007). In this respect, speculation has arisen that these supranational chains, by a number of their measures, disadvantage the goods of the Czech production compared to the foreign ones. One example of this disadvantage is the different price margins. This article addresses the issues of price levels in retail chains, in relation to the above.

The outcome of this article within the GFK Study (2017) titled as GFK Shopping Monitor has been confirmed claiming that the format of stores is a factor that allows the chain stores to implement their pricing and product strategies in the Czech Republic: $46 \%$ of customers implemented their food shopping in hypermarkets (Albert Hypermarket, Globus, Kaufland and Tesco), $16 \%$ in supermarkets (Albert Supermarket, Billa, Tesco Supermarket) and $23 \%$ in Discount Shops (Lidl, Penny Market) in 2016. An author Ambrose (1979) analyzed the prices of 54 food products in 6 small independent stores, in 4 large independent stores and in 4 stores belonging to the chain of chain stores. All of these shops were located in city centers and in suburban and rural areas of the state of Nebraska. Ambrose (1979) found out that, on average, food prices were higher in small independent stores $(0.7 \%$ higher than the overall average) and in rural stores (3.8\% higher). The largest differences in average prices $(10.1 \%)$ were found among city center shops and suburban shops for the groups of following product groups: meat, poultry and fish products. Authors Leibtag, Barker and Dutko (2010) used data from the database of Nielsen: Neilsen Homescan to analyze food purchases in approximately 40,000 US households. The authors concluded that prices in so-called "nontraditional discount food retailers" (stores such as Wal-Mart, Costco and Family Dollar) are lower than in traditional supermarkets, this claim was true for $82 \%$ of food products (after checking and comparing brands and package sizes). Expenditure weighted average prices were $7.5 \%$ lower in "nontraditional" smaller shops, food prices were lower by 3-28\%. Price differences among traditional chains (supermarkets) and other stores were found in metropolitan areas where there is a higher share of other competitors and other types of shops in relation to supermarkets. Authors Hoffmann and Senkler (2011) used data from scanning food codes and prices from 80 shops in Germany within a two-year period to evaluate price competition among different groups of retail formats (hypermarket, supermarket, discount stores, other stores). The authors compared the price levels of food items compiled into the "typical shopping basket" instead of comparing the prices of individual food products. Hoffmann and Senkler (2011) found evidence of ongoing competition among individual retail sales formats (discounts, supermarkets and hypermarkets). The regular shopping basket was compiled of 24 commonly purchased food products, the variation coefficient of a basket cost was $14.9 \%$ for discount products and $16.7 \%$ for best-selling standard products.

Graph 1 shows the format of stores in selected countries in 2013, as assessed by GFK (also referred to as GfK or Incoma GfK), but the specific parameters for the format of the stores in the GFK outputs were not found, however, it is probable, that the understanding of the formats will be similar to that of Nielsen - see Table 3.

Most of the largest multinational retail chains such as Walmart, Carrefour, Metro Group and Tesco had problems with declining profits and negative revenue growth between 2001 and 2004, not only in their domestic markets but also in their foreign networks. As a result, these companies have begun to invest significantly more in domestic markets, where historically they have made the most profits at the expense of their foreign units. The restructuring of European companies has resulted in an increase in their turnover (sales) within Europe. This is illustrated in Table 1.

Many of the European companies, respectively. groups even sold in the context of the global economic crisis of their business networks in countries where they were not strong, even though these markets are considered strategic with high potential (Table 2).

In 2016, the share of international trade chains in the overall food market in the Czech Republic exceeded 70 percent, according to GfK. The market 


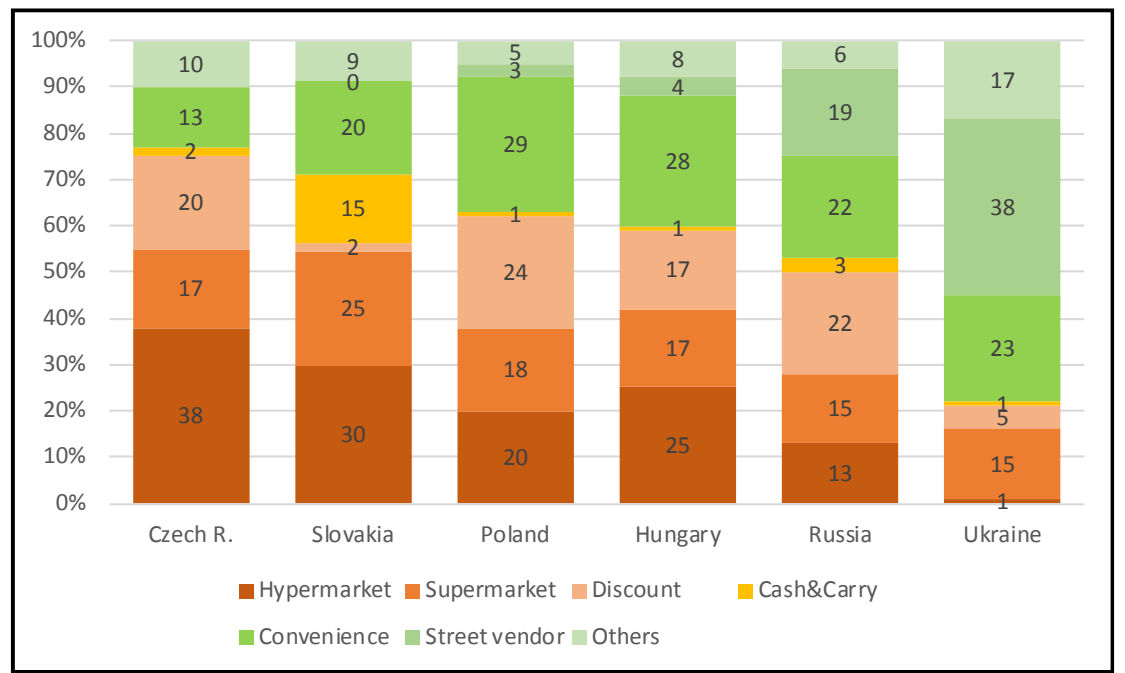

Source: GfK 2013, Retail and Future Markets

Graph 1: Formats of stores in chosen countries from middle and east Europe (year 2013, \%).

\begin{tabular}{|c|c|c|c|c|c|c|c|}
\hline \multirow{2}{*}{ Ord. } & Chain/ & \multirow{2}{*}{$\begin{array}{c}\text { Turnover in } \\
\text { Europe, mld. eur }\end{array}$} & \multirow{2}{*}{ Place } & \multirow{2}{*}{ Ord. } & Chain/ & \multirow{2}{*}{$\begin{array}{l}\text { Turnover in } \\
\text { Europe, mld. eur }\end{array}$} & \multirow{2}{*}{ Place } \\
\hline & Group & & & & Group & & \\
\hline 1 & Schwarz & $92-95^{*}$ & Germany & 6 & Edeka & $50^{*}$ & Germany \\
\hline 2 & Tesco & $63 x x$ & $\begin{array}{l}\text { Great } \\
\text { Britain }\end{array}$ & 7 & Aldi & $49^{*}$ & Germany \\
\hline 3 & Carrefour & 56 & France & 8 & E.Leclerc & $43.4 x x$ & France \\
\hline 4 & Rewe & $55^{*}$ & Germany & 9 & ITM & $40.2 x x$ & France \\
\hline 5 & Metro / Media Saturn & 54 & Germany & 10 & Auchan & 38.5 & France \\
\hline
\end{tabular}

Note: *estimation, $\mathrm{xx}$ turnover within fuel trade

Source: Retail-index.com, Veraart Research Group BV, The Netherlands, 2016, http://www.retail-index.com/Sectors/FoodRetailersinEuropeandworldwide.aspx

Table 1: TOP 10 food retailers in Europe, year 2016.

\begin{tabular}{|c|c|c|c|c|}
\hline Group/Company & Turnover & SUM & $\%$ & Chain** \\
\hline 1. KAUFLAND ČR/ Group Schwarz & 55.23 & 55.23 & 14.1 & Kaufland (124) \\
\hline 2. AHOLD CZECH REPUBLIC & 48.33 & 103.56 & 12.3 & Albert hypermarket (91), supermarket (240) \\
\hline 3. TESCO STORES ČR & 41.76 & 145.32 & 10.7 & $\begin{array}{l}\text { Hypermarket (76), hypermarket Extra (9), } \\
\text { supermarket (62), OD/City/My (6), Expres (45) }\end{array}$ \\
\hline 4. LIDL ČR/Group Schwarz & 33.66 & 178.98 & 8.6 & Lidl (231) \\
\hline 5. PENNY MARKET/Group Rewe & 32.13 & 211.11 & 8.2 & Penny Market (360) \\
\hline 6. MAKRO CASH \& CARRY ČR & 30.12 & 241.23 & 7.7 & Makro (13), Drive In (2) \\
\hline 7. GECO & 29.98 & 271.21 & 7.6 & Geco tobacco-newspaper (262) \\
\hline 8. GLOBUS ČR & 22.93 & 294.14 & 5.9 & Globus (15) \\
\hline 9. BILLA / group Rewe & 21.62 & 315.76 & 5.5 & Billa (205), Billa stop \& shop (43) \\
\hline 10. JIP VÝCHODOČESKÁ & 11.40 & 327.16 & 2.9 & $\begin{array}{l}\text { JIP (35), JIP Plus (144), Cash \& Carry (12), } \\
\text { Wholesale (17) }\end{array}$ \\
\hline $11-30$. subject & 64.77 & 391.93 & 16.5 & $x x x$ \\
\hline from these group $\mathrm{COOP}$ & 26.16 & $\mathrm{x}$ & 6.7 & Group COOP \\
\hline
\end{tabular}

Note: Turnover $=$ sales in $v$ billion CZK, without VAT, SUM $=$ cumulative sales, $\%=$ share of the trader $/$ group on TOP 30 (it means share on the total sales of 30 traders with the highest sales volume in the Czech Republic), ${ }^{* *}=$ sum of own markets in October 2016

Source: GfK (2017), Špačková (2016), own calculations

Table 2: Analysis of the largest traders / business groups in the Czech Republic, with the predominance of quick-moving goods, according to sales, year 2015-2016. 
was more and more segmented. All major traders have crossed the annual turnover line of CZK 20 billion and have thus been strongly allocated to the rest of the market. Most recently, the group Schwarz (Kaufland and Lidl), followed by Rewe (Penny Market and Billa) Makro Cash \& Carry and Globus also had a stable position at the top of the deal, according to Skala, Director of Retail \& Shopper research at GfK Czech (Špačková, 2016).

The main objective is to verify whether it is possible to confirm differences in price policy not only in the division of chains according to the format of the shops but also in relation to Czech and foreign food and whether these findings can be clearly identified. The partial objective is to find the difference between Czech and foreign products in the context of chain approach according to other criteria such as price differences among products and among chains.

In this context, the outline of confirming the influence of multinational retail companies on their pricing policy in relation to the market share should also emerge.

\section{Materials and methods}

The used underlying data is based on the data processed from the primary data obtained by the data collection in the retail chains as part of the food price survey (Smutka, Řezbová and Škubna, 2017) transformed into aggregated underlying tables for individual chains. There are eleven chains evaluated in the tables as well as 29 relevant food groups. These 11 tables allow Excel to evaluate directly the average numbers of observations. Omitting food with zero observations or price observation is done by manual correction. Determining the number of items without observation with price is done by enumeration. Similarly, the determination of the overall variability, with which the chains operate, is based on the values of the variation coefficient with correction of the zero-point observation and the zero observation with price. Observation with price is more important in these analyzes than the total number of observations in the context of item inclusion in the calculation. The evaluation of the offer (range of assortment) of individual foods is thus processed with the help of manual correction of zero observation of Czech and foreign food of individual chains. The zero observation values are not taken into account for the total number of observations. The number of observations with the price in percentage of the total number of observations is based on the total numbers. Used data about the number of stores and about the market share are based on the data given in Špačková (2016), the calculations are simple divisions and sums.

Average prices are used when ranking prices in chains in order from the cheapest. However, the groups of dairy, meat and other products are used in this case. The division of individual foods into these groups is as follows (and applies to other analyzes performed in this section) - dairy products (milk $1.5 \%$, eidam $30 \%$, eidam $40 \%$, white mold cheese, fresh cheese, cream cheese, white yoghurt, fruit yoghurt, sour cream, butter), meat products (pork legs, pork neck, pork shoulder, beef back, beef front, fine sausages, paprika sausage, pork ham, fresh chicken, frozen chicken) other products (toast bread, sweet pastry - cake , biscuits, eggs, rapeseed oil, sunflower oil, spaghetti, chocolate, gelatin candies). The original divisoin by food was used primarily, not by the chains, and the order of the chains was determined from the 29 food information tables according to the average prices of individual food from lowest to highest. If there were specific food available in all 11 monitored chains, the ranking of values was set from 1 to 11 . If the food was not tracked (not observed or not observed with price), it was ranked outside the ranked order. For this reason the order has always been from 1, but the maximum value has often not reached 11. This was done separately for Czech and foreign foods. Overall, it meant the creation of 6 tables with 10 or 9 Czech and foreign food and 11 columns representing individual chains. The focus is set in a simple order. To eliminate possible risks of this evaluation the number of values of chain placement in the order was analyzed among tree cheapest foods. This number of placements is performed by a visual evaluation and sum without the use of computational tools in Excel. Therefore the highest number of placements among the three cheapest foods in a given food group implies an assumption for the chain's approach to price policy among other chains in terms of maintaining a low price.

The dependencies of the monitored indicators are evaluated in the context of the correlation principles. The dependence of two quantitative variables (when it is not decided which one is independent and which dependent variable) is statistically illustrated by the correlation coefficient. The correlation coefficient (r) has values in the range of -1 to 1 inclusive. If $\mathrm{r}=0$, the quantitative variables are independent, $r=1$ means direct dependence and $\mathrm{r}=-1$ is indirect 
dependence. The CORREL function was used in Excel for calculation. It works on the Pearson correlation coefficient principle which means it works with linear dependence. The division of chains is used according the store format of the chain. For this purpose, the prevailing type of shop format was considered. This was consulted with different sources and the resulting division corresponds to the general assumptions about the types of formats of the individual chains. Můj obchod and Žabka are being considered smallformat chains according to the type of shops. Most of the chain stores are in the category of medium format stores (supermarkets, discounts) - Albert, Billa, COOP, Lidl, Norma, Penny Market. Largeformat chain stores (may be called hypermarkets) are Globus, Kaufland and Tesco. For Albert (medium and large format), Billa (small and medium format), COOP (all types of formats) and Tesco (all types of formats), the classification according to the above mentioned principles corresponds to the prevailing type of store format. COOP is also taken into account when calculating the number of stores.

\section{Results and discusion}

There were 15,294 shops with grocery and mixed goods in the Czech Republic in 2016. Their number has fallen by four percent since 2013. Mostly the small shops have disappeared. The number of supermarkets has also decreased by 28 in the last three years. In contrast, 19 hypermarkets have been added. Supermarkets and hypermarkets together represent $80 \%$ of the total turnover of the food and grocery stores, which is the highest share in Central Europe. This was the result of the latest Nielsen survey (Nielsen Census, 2016) (Table 3).

There are markable differences among the chains in the range of assortment defined according to 29 analyzed products of Czech and foreign origin (Table 4).

If it could be assumed that an adequate Czech or foreign product could be found in the event of a visit, then it is possible to state that not the whole range of Czech products are in Lidl chain (5 Czech products are missing), Můj obchod (4 products), Norma (4 products), Žabka (4 products) and one missing product is in Penny Market. Analogically, the complete range of monitored foreign products is available only in Tesco, 27 items have Kaufland and Lidl, followed by Albert and Billa (26 items) and Penny Market (22 foreign products). The following would probably be Můj Obchod and Norma (22 foreign products) and Žabka (20 products) but it is unlikely to happen (taking into account not visiting the chains). With a high probability it is possible to state that COOP chain is focused on Czech products in the context of this comparison (in 12 cases it does not offer an adequate foreign product to the offered Czech one) and it is followed by Globus (10 demonstrable cases where it does not offer an adequate foreign product to the Czech one). The behaviour of Globus is also interesting in the context of the other two large-format chains, as their offer of Czech and foreign products is almost complete (Table 5).

With the exception of Můj Obchod chain, it is possible to say that the six chains with the highest number of observations are the same as the six chains with the highest number of stores (Albert, Billa, Kaufland, Lidl, Penny Market, Tesco). However, the availability, with regard to the way of data collection, was reflected in the shops, for example Penny Market, which has 360 stores ( $2^{\text {nd }}$ place and $1^{\text {st }}$ place without taking in account Můj Obchod chain) was ranked on the 6th place according to observation. On the other hand, Kaufland, which

\begin{tabular}{|l|r|r|r|r|r|r|r|c|}
\hline Parameter & \multicolumn{1}{|c|}{$\mathbf{2 0 0 0}$} & $\mathbf{2 0 1 1}$ & $\mathbf{2 0 1 2}$ & $\mathbf{2 0 1 3}$ & $\mathbf{2 0 1 4}$ & $\mathbf{2 0 1 5}$ & $\mathbf{2 0 1 6}$ & $\mathbf{2 0 1 6 / 2 0 0 0}$ \\
\hline within $50 \mathrm{~m}^{2}$ & 10662 & 8129 & 8158 & 7524 & 7256 & 6969 & 6619 & $62.1 \%$ \\
\hline $51-100 \mathrm{~m}^{2}$ & 5254 & 4235 & 4235 & 4408 & 4553 & 4574 & 4679 & $89.1 \%$ \\
\hline $101-200 \mathrm{~m}^{2}$ & 2208 & 1734 & 1679 & 1738 & 1819 & 1830 & 1826 & $82.7 \%$ \\
\hline $201-400 \mathrm{~m}^{2}$ & 837 & 608 & 635 & 613 & 553 & 544 & 518 & $61.9 \%$ \\
\hline Supermarket $401-2500 \mathrm{~m}^{2}$ & 900 & 1291 & 1330 & 1362 & 1352 & 1349 & 1334 & $148.2 \%$ \\
\hline Hypermarket over $2500 \mathrm{~m}^{2}$ & 68 & 273 & 287 & 299 & 309 & 314 & 318 & $467.6 \%$ \\
\hline TOTAL & 19929 & 16270 & 16324 & 15944 & 15842 & 15580 & 15294 & $76.7 \%$ \\
\hline
\end{tabular}

Note: Within 50 square meters Nielsen defines "small grocery stores", 51-400 $\mathrm{m}^{2}$ "medium and large grocery stores", 401-2500 $\mathrm{m}^{2}$ "supermarkets" and over $2500 \mathrm{~m}^{2}$ "hypermarkets"; for "discounts" there is no strict division by area, however, an area of $400-1000 \mathrm{~m}^{2}$ can be considered and thus included in a subset of supermarkets; In this context it is possible to include the above mentioned formats into three categories: small format (up to $200 \mathrm{~m}^{2}$ ), medium format (cca $200-2500 \mathrm{~m}^{2}$ ), large format (over $2500 \mathrm{~m}^{2}$ ). Source: Nielsen Census (2016), own calculations, divided by sales formats

Table 3: Number of groceries and mixed goods stores in the Czech Republic for 2000-2016. 


\begin{tabular}{|l|c|c|c|}
\hline RETAIL CHAIN & $\begin{array}{c}\text { Offer of Czech food products } \\
\text { in analyzed sample (0 - 29) }\end{array}$ & $\begin{array}{c}\text { "Chain was not visited how many } \\
\text { times“ (amount of analyzed food } \\
\text { products in the chain) }\end{array}$ & $\begin{array}{c}\text { Offer of foreign food } \\
\text { products in analyzed } \\
\text { sample (0 - 29) }\end{array}$ \\
\hline Albert $^{2}$ & 29 & $0(29)$ & 26 \\
\hline Billa $^{2}$ & $0(29)$ & 26 \\
\hline COOP $^{2}$ & 29 & $2(27)$ & 15 \\
\hline Globus $^{3}$ & 27 & $0(29)$ & 19 \\
\hline Kaufland $^{3}$ & 29 & $0(29)$ & 27 \\
\hline Lidl $^{2}$ & 29 & $0(29)$ & 13 \\
\hline Můj obchod $^{1}$ & 24 & $9(20)$ & 13 \\
\hline Norma $^{2}$ & 16 & $9(20)$ & 22 \\
\hline Penny Market $^{2}$ & 16 & $0(29)$ & 29 \\
\hline Tesco $^{3}$ & 28 & $0(29)$ & 17 \\
\hline Žabka $^{1}$ & 29 & $3(26)$ & 13 \\
\hline
\end{tabular}

Notice: ${ }^{1}$ small format chains, ${ }^{2}$ medium format stores (supermarkets, discounts), ${ }^{3}$ large format chain stores (hypermarkets) Source: Own data collection, November 2016

Table 4: The offer (range of assortment) of individual foods in chains.

\begin{tabular}{|l|c|c|c|c|c|c|}
\hline RETAIL CHAIN & $\begin{array}{c}\text { Number of } \\
\text { observations }\end{array}$ & $\begin{array}{c}\text { Number of } \\
\text { observations } \\
\text { with price }\end{array}$ & $\begin{array}{c}\text { Sum of items } \\
\text { without } \\
\text { observations } \\
\text { with price }\end{array}$ & $\begin{array}{c}\text { Number of } \\
\text { observations }\end{array}$ & $\begin{array}{c}\text { Number of } \\
\text { observations } \\
\text { with price }\end{array}$ & $\begin{array}{c}\text { Sum of items } \\
\text { without } \\
\text { observations } \\
\text { with price }\end{array}$ \\
\hline & \multicolumn{3}{|c|}{ CZECH PRODUCTS } & \multicolumn{3}{|c|}{ FOREIGN PRODUCTS } \\
\hline TOTAL & 42.96 & 37.00 & & 42.96 & 29.40 & \\
\hline Albert2 & 82.55 & 76.17 & 0 & 82.55 & 48.92 & 3 \\
\hline Billa2 & 72.66 & 67.34 & 0 & 72.66 & 46.85 & 3 \\
\hline COOP2 & 11.48 & 10.52 & 2 & 11.48 & 8.13 & 14 \\
\hline Globus3 & 15.86 & 15.24 & 0 & 15.86 & 14.63 & 10 \\
\hline Kaufland3 & 67.41 & 60.00 & 0 & 67.41 & 44.19 & 2 \\
\hline Lid12 & 62.79 & 38.29 & 5 & 62.79 & 46.85 & 2 \\
\hline Můj obchod1 & 7.20 & 6.88 & 13 & 7.20 & 5.77 & 16 \\
\hline Norma2 & 8.00 & 7.94 & 13 & 8.00 & 6.00 & 16 \\
\hline Penny & 53.48 & 49.89 & 1 & 53.48 & 30.36 & 7 \\
\hline Market2 & 68.07 & 54.03 & 0 & 68.07 & 53.00 & 0 \\
\hline Tesco3 & 23.00 & 20.64 & 7 & 23.00 & 18.71 & 12 \\
\hline Žabka1 & 23.00 & 20.64 & 7 & 23.00 & 18.71 & 12 \\
\hline
\end{tabular}

Notice: ${ }^{1}$ small format chains, ${ }^{2}$ medium format stores (supermarkets, discounts), ${ }^{3}$ large format chain stores (hypermarkets) Source: Own data collection, November 2016

Table 5: Average number of observations per food observed in the chain.

is on the $2^{\text {nd }}$ place in number of observations, has 124 stores and is the $7^{\text {th }}$, respectively the $6^{\text {th }}$. From this point of view, the availability by public transportation and location of stores is obvious in this context with regard to the optimization of the route for the purpose of data collection. It is also possible to think about the influence by the methodology of data collection.

The ratio between the number of observations with the price and the total number of observations is given in relative terms in Table 6 . It is obvious that the number of observations with price is higher almost in all chains for Czech products than for foreign ones, which corresponds to the overall average. The only exception is Lidl chain, where the observation with price of foreign products is dominant. It is also worth mentioning Tesco stores, where the observations with price for Czech and foreign products are almost equal. From the dependence point of view, there is a correlation coefficient of 0.88 in between the absolute values for the number of observations with price for Czech and foreign products, while the correlation coefficient for comparison 


\begin{tabular}{|l|c|c|}
\hline RETAIL CHAIN & $\begin{array}{c}\text { Number of obserations with price in \% } \\
\text { from total number of observations - Czech } \\
\text { products }\end{array}$ & $\begin{array}{c}\text { Number of obserations with price in \% } \\
\text { from total number of observations - foreign } \\
\text { products }\end{array}$ \\
\hline AVERAGE & 83 & 56 \\
\hline Albert $^{2}$ & 92 & 53 \\
\hline Billa $^{2}$ & 93 & 58 \\
\hline COOP $^{2}$ & 92 & 39 \\
\hline Globus $^{3}$ & 96 & 60 \\
\hline Kaufland $^{3}$ & 89 & 61 \\
\hline Lidl $^{2}$ & 50 & 69 \\
\hline Můj obchod $^{1}$ & 76 & 52 \\
\hline Norma $^{2}$ & 79 & 49 \\
\hline Penny Market $^{2}$ & 90 & 43 \\
\hline Tesco & 79 & 78 \\
\hline Žabka $^{1}$ & 76 & 53 \\
\hline
\end{tabular}

Notice: ${ }^{1}$ small format chains, ${ }^{2}$ medium format stores (supermarkets, discounts), ${ }^{3}$ large format chain stores (hypermarkets) Source: Own data collection, November 2016

Table 6: Number of observations with a price in proportion to the total number of observations.

of number of observations with price and total number of observation is 0,96 and is the same as for foreign products.

The products were divided into three groups (dairy, meat, other) from the price evaluation point of view and not only in the context of Czech and foreign products, but also with the inclusion of product price comparisons among idividual chains. For each product there is a ranking in terms of average prices. Considering that the consumer reacts to the price and at the same time it is important for him to compare the product as "cheaper / more expensive" no matter how cheaper is the product than competition, the order was determined regardless of the relative expression. The aggregate results are shown in Table 7 but it does not show results based on ranking from 1 to 11 (according to the number of chains), but only the aggregated values for the position of the chain at the first three places in the ranking of average food prices from the cheapest to the most expensive. The cheapest dairy products are most often in Lidl, for both Czech and foreign products. Next position has Kaufland and Albert for Czech dairy products and Penny Market with Kaufland for foreign dairy products. The cheapest Czech meat products can be found in Globus, further in Kaufland and Penny Market (both 5 placements). The cheapest foreign products can be found in Albert and Tesco (equally 6 placements) followed by Kaufland. The cheapest Czech products included in the group of other products are offered by Penny Market, and in other places there are 5 chains with three placements. The cheapest foreign products are offered in this group by Lidl, followed by Norma and Penny Market.

If individual placements were aggregated, then Lidl is the cheapest for Czech products (14 placements), followed by Penny Market (13 placemets), and Globus (12 placements) would be closely followed by Kaufland (11 placements). Compared with the assumptions, it is not true that large format chains are cheaper, even Tesco is among the three cheapest products represented less often than Billa, Albert, COOP, Norma and even Můj obchod. On the other hand, the placement of small-format chains corresponds to the assumptions and their focus. The cheapest aggregated placements of foreign products are once again in Lidl chain (21 placements), followed by Penny Market (15 placements) and Kaufland (11 placements). In addition, there are 10 placements in Albert and Norma, Tesco with 7 placements and Billa with 4 placements. Globus as the large-format chain was not very cheap in this comparison (3 placements), and is closer to the small format stores as Můj Obchod (2) and Žabka (1). COOP has also achieved only 2 placements, but its approach to foreign food has already been indicated by the results of other analyzes. When evaluating the approach of the chains to Czech and foreign products in this context, it is difficult to find a generalizable output, which is not appropriate to solve aggregately for a group of other products with a respect of the heterogeneity of the products. Globus and Tesco have the biggest difference in the number of placements of dairy and meat products, Globus is ranked 7 times among the cheapest Czech meat products but not once among foreign meat products. On the other hand, 


\begin{tabular}{|c|c|c|c|c|c|c|}
\hline \multirow[t]{2}{*}{ RETAIL CHAIN } & $\begin{array}{c}\text { Dairy } \\
\text { products }\end{array}$ & $\begin{array}{c}\text { Meat } \\
\text { products }\end{array}$ & $\begin{array}{c}\text { Other } \\
\text { products }\end{array}$ & $\begin{array}{c}\text { Dairy } \\
\text { products }\end{array}$ & $\begin{array}{c}\text { Meat } \\
\text { products }\end{array}$ & $\begin{array}{c}\text { Other } \\
\text { products }\end{array}$ \\
\hline & \multicolumn{3}{|c|}{ CZECH PRODUCTS } & \multicolumn{3}{|c|}{ FOREIGN PRODUCTS } \\
\hline Albert $^{2}$ & 4 & 2 & 1 & 1 & 6 & 3 \\
\hline Billa $^{2}$ & 3 & 3 & 3 & 0 & 3 & 1 \\
\hline $\mathrm{COOP}^{2}$ & 2 & 1 & 3 & 1 & 1 & 0 \\
\hline Globus $^{3}$ & 2 & 7 & 3 & 2 & 0 & 1 \\
\hline Kaufland $^{3}$ & 4 & 5 & 2 & 4 & 5 & 2 \\
\hline $\operatorname{Lidl}^{2}$ & 8 & 3 & 3 & 9 & 4 & 8 \\
\hline Můj obchod $^{1}$ & 1 & 1 & 3 & 2 & 0 & 0 \\
\hline Norma $^{2}$ & 3 & 2 & 1 & 3 & 1 & 6 \\
\hline Penny Market ${ }^{2}$ & 3 & 5 & 5 & 6 & 3 & 6 \\
\hline Tesco $^{3}$ & 0 & 1 & 2 & 1 & 6 & 0 \\
\hline Žabka $^{1}$ & 0 & 0 & 1 & 1 & 0 & 0 \\
\hline
\end{tabular}

Notice: ${ }^{1}$ small format chains, ${ }^{2}$ medium format stores (supermarkets, discounts), ${ }^{3}$ large format chain stores (hypermarkets) Source: Own data collection, November 2016

Table 7: Number of placements of chain among three cheapest food groups.

Tesco is only once placed among Czech products but 6 times among foreign ones. The difference among placements in other chains is up to 3 placements at maximum. If the possible dependence between the placement of Czech products and the location of foreign products according to individual product groups were evaluated, then there is a strong dependence only for dairy products, where the correlation coefficient is 0.75 . On the other hand, the coefficient for meat products is only 0.06 so there is almost no dependence. The dependence for the group of other products is 0.19 in terms of the value of correlation coefficient.

\section{Conclusion}

When talking about number of observations with price per product, most of the Czech products are in Albert, Billa and Kaufland and foreign food in Tesco, Albert, Lidl and Billa. The total number per average number of observations of one item is about 43 observations of which 37 Czech products observations and about 29 of foreign products with price. It is also an evidence in favor of Czech products and its superiority compared to foreign products within the analyzed 29 foods which have been selected. Only Lidl has a higher number of price observations from the total number of observations of foreign products. The number of shops of individual chains is used not only for these reasons but also because it can be related to space availability of the stores and to other parametrers.

It is also important to mention the overall figure per the average number of observations of one item, which is about 43 observations, of which 37 observations of Czech products and about 29 products with price, which is an evidence in favor of Czech products and its superiority compared to foreign products within the analyzed 29 foods which have been selected.

However, according to the methodology used in data collection, it is necessary to specify that the listed average numbers of product observations are also affected by the space availability of the shops. The average number of observations per product was 82.55 in Albert, followed by Billa with 72.66 observations, followed by Tesco (about 68 observations), Kaufland with 67.41 observations and Lidl with 62.79 observations. There were 7.2 observations the least and it was in Můj Obchod, followed by Norma with 8 observations and the COOP chain with about 11.5 observations. When evaluating whether there is any difference between Czech and foreign products in the context of approach of the chains according to other criteria such as the price difference among products and among the chains, this is evaluated mainly by correlation coefficients which indicate possible dependence of monitored indicators within individual chains and which point to some differences, however, these are not statistically conclusive. In the area of price policy evaluation (whether it is possible to confirm the differences not only in the division of the chains according to the format of the stores, but also in relation to Czech and foreign foods and identify clearly these findings), the difference is considered mainly according to the "low price" 
of food and it can be said that there are noticeable differences among the chains, which also confirm different approach to Czech and foreign food and differences according to the format of chain stores.

The authors Richards and Hamilton (2006) show in their study that the US food chains choose their competitive advantages based on two parameters: the price level and the width (range) of food products. The significant impact of household income on the level of food prices in the basic consumer basket was also reflected in the study by the team of authors Binkley and Conner (1996).

\section{Acknowledgements}

This paper originated in the context of the exploratory study „Prices of selected Czech and foreign food products in retail chains in November 2016". The study was created for the needs of the Ministry of Agriculture of the Czech Republic.

Corresponding author:

Ing. Ondřej Škubna

Department of Economics, Faculty of Economics and Management, Czech University of Life Sciences Prague Kamýcká 129, 16500 Prague 6, Czech Republic

Phone: +420 22438 2079, E-mail: skubna@pef.czu.cz

\section{References}

[1] Ambrose, D. M. (1979) "Retail grocery pricing: inner city, suburban, and rural comparisons“, The Journal of Business, Vol. 52, No. 1, pp. 95-102. ISSN 0021-9398.

[2] Bielik, P., Smutka, L., Svatoš, M. and Hupková, D. (2013) "Czech and Slovak agricultural foreign trade - Two decades after the dissolution“, Agricultural Economics, Vol. 59, No. 10, pp. 441-453. ISSN 0139-570X.

[3] Binkley, J., K. and Connor, J. M. (1996) "Market Competition and Metropolitan-Area Food Prices“, Staff Paper 96-15, Department of Agricultural Economics, Purdue University, July 1996.

[4] Hoffmann, A. and Senkler, H. (2011) "Interformat Price Competition of Multi-Product Retailers: Evidence for German Grocery Retailing“, EAAE Congress; Zurich, Switzerland, August 30-September 2.

[5] GFK (2017) "GFK Shopping Monitor", [Online]. Available: http://www.gfk.com/cz/insights/report/ gfk-shopping-monitor-2017. [Accessed: 27 Feb. 2017].

[6] Nielsen Census (2016) "Trends in the structure of retail food formats for 2016" (Trendy ve struktuře prodejních kanálů potravin za rok, in Czech). [Online]. Available: http://www.nielsen. com/cz/cs/insights/news/2016/trendsin-the-structure-of-sales-channels-of-food-for-2016.html. [Accessed: 28 Nov. 2016].

[7] Leibtag, E., Barker, C. and Dutko, P. (2010) "How Much Lower Are Prices at Discount Store? An Examination of Retail Food Prices“, USDA-ERS: Washington, Economic Research Report No. 105, October.

[8] Maitah, M., Řezbová, H., Smutka, L. and Tomšík, K. (2016) "European Sugar Production and its Control in the World Market“, Sugar Tech, Vol. 18, No. 3, pp. 236-241. ISSN 0974-0740.

[9] Pulkrábek, J., Peterová, J., Řezbová, H. and Urban, J. (2007) "Competitive ability and economy of bioethanol production crops“, Listy Cukrovarnicke a Reparske, Vol. 123, No. 7-8, pp. 216 - 220. ISSN 1805-9708.

[10] RETAIL-INDEX (2016) "Retail-index.com", Veraart Research Group BV, The Netherlands. [Online]. Available: http://www.retail-index.com/Sectors/FoodRetailersinEuropeandworldwide. aspx. [Accessed: 07 Dec. 2016].

[11] Richards, T. J. and Hamilton, S. F. (2006) "Rivalry in price and variety among supermarket retailers", American Journal of Agricultural Economics, Vol. 88, No. 3, pp. 710-726. ISSN 0002-9092. 
[12] ̌ezbová, H. and Tomšík, K. (2012) "Impact of complementary national direct payments on cattle breeding sector", AGRIS on-line Papers in Economics and Informatics, Vol. 4, No. 4 - Special, pp. 95-106. ISSN 1804-1930.

[13] Smutka, L. and Burianová, J. (2013) "The competitiveness of Czech agrarian trade within the context of the global crisis“, Agricultural Economics, Vol. 59, No. 4, pp. 183-193. ISSN 0139-570X

[14] Smutka, L., ̌̌ezbová, H. and Pulkrábek, J. (2016) "Production capacity distribution in EU market - Who does take control over available capacities?", Listy Cukrovarnicke a Reparske, Vol. 132, No. 2, pp. 71 - 77. ISSN 1805-9708.

[15] Smutka, L., ̌̌ezbová, H. and Škubna O. (2017) "Prices of selected Czech and foreign food products in retail chains in November 2016“ (Ceny vybraných českých a zahraničních potravin v řetězcích v listopadu 2016, in Czech), Research Study - for the needs of the Ministry of Agriculture of the Czech Republic, FEM, CULS Prague, January, 2017.

[16] Svatoš, M. and Smutka, L. (2012) "Development of agricultural trade and competitiveness of the commodity structures of individual countries of the Visegrad Group", Agricultural Economics, Vol. 58, No. 5, pp. 222-238, ISSN 0139-570X.

[17] Špačková, I. (2016) "The biggest chains in the Czech Republic: Kaufland leads the new ranking, Albert andLidlalsoimproved theirposition“"(NejvětšířetězcevČesku:NovýžebříčekvedeKaufland, polepšily si Albert a Lidl, In Czech). [Online]. Available: https://zpravy.aktualne.cz/finance/nakupovani/ nejvetsi-retezce-v-cesku-novy-zebricek-vede-kaufland-polepsir $\sim$ cd9642fec75a11e6aa860025900f ea04/. [Accessed: 22 April 2017].

[18] Špička, J. and Smutka, L. (2014) "The technical efficiency of specialised milk farms: A regional view“" Scientific World Journal, Vol. 2014, Art. No. 985149. ISSN 1537-744X. DOI 10.1155/2014/985149. 